\title{
Pengaruh Budgetary Goal Characteristics, Komitmen Organisasi, Dan Motivasi Pada Kinerja Manajerial dengan Gaya Kepemimpinan Sebagai Variabel Moderasi
}

\author{
Ida Ayu Misdiantari Aristiani ${ }^{1}$ \\ Ni Putu Sri Harta Mimba ${ }^{2}$ \\ ${ }^{1,2}$ Fakultas Ekonomi dan Bisnis Universitas Udayana (Unud), Bali, Indonesia \\ e-mail: dayumisdiantari@yahoo.co.id
}

\begin{abstract}
ABSTRAK
Penelitian ini bertujuan untuk mengetahui pengaruh budgetary goal characteristics, komitmen organisasi, dan motivasi pada kinerja manajerial dengan gaya kepemimpinan transformasional sebagai variabel moderasi. Penelitian ini dilakukan pada Pemerintahan Kota Denpasar. Teknik analisis data yang digunakan yaitu Uji Moderated Regression Analysis. Populasi dalam penelitian ini berjumlah 31 SKPD dan jumlah sampel dalam penelitian ini adalah 93 orang. Berdasarkan hasil penelitian disimpulkan bahwa 1)budgetary goal characteristics berpengaruh negatif pada kinerja manajerial (signifikansi 0,375); 2)komitmen organisasi berpengaruh positif pada kinerja manajerial (signifikansi 0,081); 3)motivasi berpengaruh positif pada kinerja manajerial (signifikansi 0,000 ); 4)gaya kepemimpinan transformasional dapat memoderasi (memperkuat) pengaruh budgetary goal characteristics pada kinerja manajerial (signifikansi 0,034); 5)gaya kepemimpinan transformasional tidak dapat memoderasi (memperlemah) pengaruh komitmen organisasi pada kinerja manajerial (signifikansi 0,769); 6)gaya kepemimpinan mampu memoderasi (memperkuat) pengaruh motivasi pada kinerja manajerial (signifikansi 0,003).
\end{abstract}

Kata Kunci: Budgetary goal characteristics, komitmen organisasi, motivasi, kinerja manajerial, gaya kepemimpinan transformasional.

\begin{abstract}
This study aims to determine the effect of budgetary goal characteristics, organizational commitment, and motivation on managerial performance using transformational leadership style as a moderating variable. This research was conducted on the Denpasar City Government. The data analysis technique used is Test Moderated Regression Analysis. The population in this study amounted to 31 SKPD and the number of samples in this study were 93 people. This study concluded that 1)budgetary goal characteristics negatively affected managerial performance (significance 0.375); 2)organizational commitment has a positive effect on managerial performance (significance 0.081); 3)motivation has a positive effect on managerial performance (significance 0,000); 4)transformational leadership style can moderate (strengthen) the influence of budgetary goal characteristics on managerial performance (significance 0.034); 5)transformational leadership style cannot moderate (weaken) the influence of organizational commitment on managerial performance (significance 0.769); 6)leadership style was able to moderate (strengthen) the effect of motivation on managerial performance (significance 0.003).

Keywords: Budgetary goal characteristics, organizational commitment, motivation, managerial performance, transformational leadership style
\end{abstract}




\section{PENDAHULUAN}

Anggaran mempunyai peranan penting bagi suatu organisasi atau instansi karena anggaran merupakan alat manajemen yang dapat digunakan untuk mengendalikan operasional organisasi agar strategi yang sudah ditetapkan dapat digunakan untuk mencapai tujuan organisasi atau instansi. Anggaran didefinisikan sebagai berikut:

"A financial operating plan for a given period embodying estimated expediture for providing service and the proposal means of financing them". Anggaran organisasi publik mencakup rencana-rencana tentang berapa biaya atas rencana yang dibuat dan berapa banyak serta bagaimana cara memperoleh uang untuk mendanai rencana tersebut. Anggaran sektor publik merupakan instrumen akuntabilitas atas pengelolaan dana publik dan pelaksanaan program-program yang dibiayai dengan uang publik (Mardiasmo, 2009). Anggaran merupakan komponen utama dari perencanaan yaitu perencanaan keuangan untuk masa depan yang memuat tujuan dan tindakan dalam mencapai tujuan organisasi tesebut. Anggaran merupakan alat perencanaan dan pengendalian manajerial.

Kinerja manajerial merupakan salah satu faktor yang dapat dipakai untuk meningkatkan efektivitas organisasi (Handoko, 1996). Kinerja manajerial didasarkan pada fungsi-fungsi manajemen yang ada dalam teori manajemen klasik, yaitu seberapa jauh manajer mampu melaksanakan fungsi-fungsi manajemen yang meliputi: perencanaan, investigasi, koordinasi, evaluasi, supervisi, pemilihan staf, negosiasi dan perwakilan. Kinerja manajerial menunjukkan kemampuan dan kemampuan perestasi seorang manajer dalam menjalankan organisasi untuk mewujudkan tujuan yang mengarah kepada 
tercapainya pelayanan publik. Kinerja manajerial dibutuhkan untuk menilai seberapa jauh lembaga organisasi dapat menerapkan visi, misinya agar pelayanan publik dapat terwujud. Kinerja dikatakan efektif apabila pihak-pihak bawahan mendapatkan kesempatan terlibat atau berpartisipasi dalam proses penyusunan anggaran. Anggaran yang disusun berdasarkan akan kehendak atasan tanpa adanya partisipasi bawahan dapat menimbukan kesulitan bagi bawahan untuk mempercayainya. Sebaliknya apabila anggaran disusun berdasarkan kehendak bawahan maka dapat menimbulkan rendahnya motivasi bawahan dalam mencapai target-target yang optimal.

Variasi dalam penyusunan anggaran, manajer tingkat atas seperti direfleksikan dalam budgetary goal characteristics memiliki pengaruh yang signifikan terhadap kinerja manajer tingkat bawah (Kenis, 1979). Oleh karena itu agar pelaksanaan anggaran dapat berjalan secara efektif, penyusunan serta penerapan anggaran harus mempehatikan 5 dimensi budgetary goal characteristics, yaitu (1) partisipasi penyusunan anggaran (budgetary participation), (2) kejelasan sasaran anggaran (budget goal clarity), (3) kesulitan sasaran anggaran (budgeting goal difficulty), (4) evaluasi anggaran (budgeting evaluation), dan (5) umpan balik anggaran (budgeting feedback).

Begitu pula dengan Pemerintah Kota Denpasar dalam menjalankan kegiatan operasionalnya menggunakan anggaran untuk mengukur kinerja manajerialnya. Pada penelitian ini kinerja manajerial diukur hanya terbatas pada kinerja non finansial terkait dengan kualitas kerja yang dimiliki oleh manajer saat ikut serta mengenai perencanaan anggaran. Penelitian yang terkait dengan pengaruh 
Ida Ayu Misdiantari Aristiani dan Ni Putu Sri Harta Mimba. Pengaruh ...

budgetary goal characteristics telah banyak yang meneliti sebelumnya. Ketidaksesuaian antara hasil penelitian sebelumnya dapat diatasi dengan menggunakan pendekatan kontijensi Govindarajan (1986) yang dalam penelitian ini menggunakan variabel moderasi yaitu gaya kepemimpinan transformasional.

Penyusunan anggaran dilakukan melalui beberapa tahapan. Realisasi pendapatan dan belanja daerah Pemerintah Kota Denpasar tahun 2011-2016 dapat dilihat pada Tabel 1 .

Tabel 1.

Realisasi Pendapatan dan Belanja Daerah Pemerintahan Kota Denpasar Tahun Anggaran 2011-2016 (dalam rupiah)

\begin{tabular}{clccc}
\multirow{2}{*}{ Tahun } & \multicolumn{1}{c}{ Uraian } & Anggaran & Realisasi & Persen \\
& & & & \\
\hline \multirow{2}{*}{2011} & Pendapatan Daerah & $1.031 .164 .304 .154,43$ & $1.150 .074 .934 .945,18$ & 111 \\
& Belanja Daerah & $184.813 .730 .259,64$ & $1.100 .149 .518 .730,61$ & 92 \\
\multirow{2}{*}{2012} & Pendapatan Daerah & $1.249 .898 .530 .752,33$ & $1.379 .049 .165 .949,38$ & 110 \\
& Belanja Daerah & $1.437 .826 .085 .610,11$ & $1.309 .529 .981 .957,55$ & 91 \\
2013 & Pendapatan Daerah & $1.493 .567 .565 .178,33$ & $1.547 .605 .213 .107,47$ & 103 \\
& Belanja Daerah & $1.706 .190 .083 .585,01$ & $1.537 .883 .625 .295,64$ & 90 \\
\multirow{2}{*}{2014} & Pendapatan Daerah & $1.687 .453 .633 .925,67$ & $1.727 .968 .712 .800,33$ & 102 \\
& Belanja Daerah & $1.884 .774 .157 .744,18$ & $1.648 .378 .768 .626,23$ & 87 \\
& Pendapatan Daerah & $1.820 .251 .600 .245,84$ & $1.786 .400 .782 .070,76$ & 98 \\
& Belanja Daerah & $2.035 .203 .119 .006,45$ & $1.757 .644 .194 .261,17$ & 86 \\
2016 & Pendapatan Daerah & $1.882 .852 .410 .384,07$ & $1.945 .388 .503 .935,50$ & 103 \\
& Belanja Daerah & $2.048 .492 .741 .527,27$ & $1.871 .440 .897 .164,80$ & 91 \\
\hline \multirow{2}{*}{ Sumber: BKAD Denpasar, 2017 } & & & \\
\end{tabular}

Sumber: BKAD Denpasar, 2017

Dari laporan APBD Pemerintah Kota Denpasar pada tabet 1. dapat dilihat bahwa pendapatan lebih tinggi dari pada anggaran yang telah ditetapkan sedangkan realisasi belanja menunjukkan realisasi yang lebih rendah dan tidak mencapai $100 \%$. Hal ini menunjukan anggaran belanja tidak di gunakan secara optimal. 
Pelaksanaan anggaran dapat berjalan secara efektif apabila penyusunan anggaran dan penerapannya memperhatikan 5 dimensi budgetary goal characteristics yang terdiri dari partisipasi penyusunan anggaran, kejelasan sasaran anggaran, kesulitansasaran anggaran, umpan balik anggaran, evaluasi anggaran (Kenis, 1979). Kinerja manajerial merupakan suatu hasil yang ditunjukkan oleh manajer mengenai prestasi atau kemunduran yang dicapai oleh organisasi (Nugraha \& Aldila, 2018). Menurut Mahoney et al., (1965) yang dimaksud dengan kinerja manajerial adalah kinerja para individu anggota organisasi dalam kegiatan-kegiatan manajerial, antara lain: perencanaan, investigasi, koordinasi, supervisi, pengaturan staf (staffing), negosiasi dan representasi.kinerja dikatakan efektif apabila tujuan anggaran tercapai dan bawahan mendapat kesempatan terlibat atau berpartisipasi dalam proses penyusunan anggaran, serta memotivasi bawahan, mengidentifikasi dan melakukan negosiasi dengan atasan mengenai target anggaran, menerima kesepakatan anggaran dan melaksanakannya sehingga dapat menghindarkan dampak negatif anggaran yaitu faktor kriteria kinerja,sistem penghargaan (reward) dan konflik. Dengan adanya partisipasi dalam menyusunan anggaran menyebabkan aparat pemerintah merasa terlibat dan harus bertanggung jawab dalam pelaksanaan anggaran. Kejelasan sasaran anggaran berkaitan dengan tujuan untuk menyusun anggaran sesuai dengan tujuan yang ingin dicapai pemerintah, sedangkan evaluasi anggaran dapat dikatakan sebagai alat pengendalian terhadap kinerja anggaran, yang dapat digunakan untuk membandingkan antara anggaran 
dengan pelaksanaan sehingga dapat mengetahui penyimpangan - penyimpangan yang telah terjadi.

Penelitian sebelumnya dilakukan oleh Apsari (2013) memperoleh hasil bahwa budgetary goal characteristics berpengaruh positif dan signifikan terhadap kinerja manajerial. Hal tersebut tidak sesuai dengan hasil penelitian yang dilakukan oleh Murthi \& Sujana (2008) yang memperoleh hasil bahwa budgetary goal characteristics tidak berpengaruh terhadap kinerja manajerial. Sedangkan penelitian ini tidak sejalan dengan penelitian yang dilakukan oleh Apsari (2013) yang memperoleh hasil bahwa budgetary goal characteristics berpengaruh positif dan signifikan terhadap kinerja manajerial.Berdasarkan uraian tersebut, maka hipotesis yang dapat dirumuskan dalam penelitian ini adalah:

$\mathrm{H}_{1}$ : Budgetary goal characteristics berpengaruh positif pada kinerja manajerial

Komitmen organisasi adalah suatu keadaan dimana seseorang karyawan memihak organisasi tertentu serta tujuan tujuan dan keinginannya untuk mempertahankan keanggotaan dalam organisasi tersebut. Hapsari (2010) mengemukakan bahwa komitmen karyawan pada organisasi merupakan salah satu sikap yang mencerminkan perasaan suka atau tidak suka seorang karyawan terhadap organisasi tempat dia bekerja. Kinerja (performance) menurut Putri (2010) adalah pencapaian kerja, tindakan, perbuatan, dan lain-lain (accomplishment of work, acts, feat, etc), dalam pengertian yang lain Manning dan Curtismendefinisikan kinerja sebagai hasil yang telah dikerjakan (something done orperformed). Kinerja manajerial adalah kinerja para individu anggota organisasi dalam kegiatan manajerial, antara lain perencanaan, investigasi, 
pengkoordinasian, evaluasi, pengawasan, pengaturan staf, negosiasi, perwakilan dan kinerja secara keseluruhan. Sedangkan pandangan Putri (2010) terhadap kinerja seseorang lebih bersifat situasional, tergantung pada kondisi internal dan faktor eksternal yang melingkupi individu organisasi dalam melakukan pekerjaan.

Komitmen organisasi dapat mempengaruhi kinerja manajerial. bawahan yang memiliki komitmen organisasi yang tinggi pasti akan lebih mementingkan kepentingan organisasi dibandingkan dengan kepentingan mereka sendiri. Sehingga bawahan yang memiliki komitmen organisasi yang tinggi akan berusaha untuk mencapai tujuan organisasi dengan meningkatkan kinerja mereka.

Penelitian sebelumnya dilakukan oleh Ikramuddin (2009), Juita (2013) menyatakan bahwa komitmen organisasi berpengaruh signifikan positif terhadap kinerja manajerial. Sedangkan penelitian yang dilakukan oleh Raffika (2010) menyimpulkan bahwa komitmen organisasi tidak berpengaruh terhadap kinerja manajerial. Berdasarkan uraian tersebut, maka hipotesis yang dapat dirumuskan dalam penelitian ini adalah:

$\mathrm{H}_{2}$ : Komitmen organisasi berpengaruh positif pada kinerja manajerial

Motivasi merupakan dorongan yang menyebabkan seseorang berusaha untuk mencapai tujuan-tujuan, baik sadar ataupun tidak sadar, dan menyebabkan seseorang untuk berperilaku, yang dapat mengendalikan dan memelihara kegiatan, serta yang menetapkan arah umum yang harus ditempuh oleh seseorang tersebut. Motivasi dapat tumbuh dalam diri agen karena agen ingin memperlihatkan kinerjanya. Kinerja manajerial merupakan kinerja para individu anggota organisasi dalam kegiatan manajerial yang meliputi perencanaan, investigasi, 
koordinasi, supervise, pengaturan staf, negosiasi dan representasi. Setiap aktivitas yang dilakukan oleh seorang manajer yang memimpin unitnya akan melibatkan kombinasi dari beberapa fungsi manajerial di atas (Syafrizal \& Aknawal, 2011). Oleh karena itu, untuk membangun suatu kinerja manajerial yang efektif maka diperlukan peningkatan kesadaran dan pemahaman atas fungsi-fungsi manajerial serta peningkatan aktivitas-aktivitas yang berkaitan dengan fungsi manajerial.

Berdasarkan teori keagenan terdapat sebuah kontrak antara agen dan prinsipal. Dengan adanya kontrak tersebut agen berusaha untuk termotivasi untuk meningkatkan kinerjanya agar kinerja agen terlihat baik dimata prinsipal. Penelitian sebelumnya dilakukan oleh Caroline (2013) yang menyatakan bahwa motivasi berpengaruh positif dan signifikan terhadap kinerja manajerial, (Handoyo (2015) menyatakan bahwa terdapat hubungan positif motivasi kerja dengan kinerja karyawan. Berdasarkan uraian tersebut, maka hipotesis yang dapat dirumuskan dalam penelitian ini adalah:

$\mathrm{H}_{3}$ : Motivasi berpengaruh positif pada kinerja manajerial

Seorang pemimpin dapat mempengaruhi kinerja bawahannya. Kepemimpinan transformasional menurut Italiani (2013) merupakan kepemimpinan yang mampu menyatukan seluruh bawahannya dan mampu mengubah keyakinan, sikap, dan tujuan pribadi masing-masing bawahan demi mencapai tujuan, bahkan melampaui tujuan yang ditetapkan. Menurut Kenis (1979) kinerja manajer dapat diukur dengan menggunakan kelima dimensi budgetary goal characteristics, yaitu partisipasi penyusunan anggaran, kejelasan sasaran anggaran, kesulitan sasaran anggaran, umpan balik anggaran, dan evaluasi 
anggaran. Kelima dimensi budgetary goal characteristics tersebut saling berkaitan satu sama lain serta diharapkan dapat meningkatkan kinerja. Kinerja manajer adalah kinerja yang diukur melalui kegiatan-kegiatan manajer-manajer yang meliputi perencanaan, pengkoordinasian, pengaturan staf dan pengawasan.

Atasan yang menganut gaya kepemimpinan transformasional akan memberikan kesempatan kepada bawahan untuk ikut berpartisipasi dalam penyusunan anggaran sehingga menyebabkan kinerja bawahan lebih optimal. Bawahan yang ikut berpartisipasi dalam penyusunan anggaran mengetahui dengan jelas sasaran anggarannya dan kesulitan sasaran anggaran yang terjadi. Sehingga bawahan akan mengetahui hasil dari usahan mereka dan mereka akan merasakan keberhasilan maupun kegagalan dari kinerja mereka sehingga mereka akan lebih puas dengan hasil kinerjanya. Dengan kata lain gaya kepemimpinan transformasional ini dapat meningkatkan kepercayaan atau keyakinan bahawan yang akan berpengaruh terhadap peningkatan kinerja mereka.

Penelitian yang dilakukan oleh Arifin (2012) menyatakan bahwa partisipasi anggaran berpengaruh secara signifikan terhadap kinerja aparat, Apsari (2013) menyatakan bahwa budgetary goal characteristics memiliki pengaruh positif dan signifikan terhadap kinerja manajerial. Tetapi penelitian ini tidak sejalan dengan penelitian yang dilakukan oleh Murthi \& Sujana (2008) bahwa budgetary goal characteristics tidak berpengaruh positif terhadap kinerja manajerial, Berdasarkan uraian tersebut, maka hipotesis yang dapat dirumuskan dalam penelitian ini adalah:

$\mathrm{H}_{4}$ : Gaya kepemimpinan transformasional memperkuat pengaruh budgetary goal characteristics pada kinerja manajerial. 
Gaya kepemimpinan transformasional merupakan gaya kepemimpinan yang kharismatik dan mempunyai peran sentral dan peran strategis dalam membawa organisasi mencapai tujuannya (Satriowati dkk., 2016). Komitmen organisasi merupakan suatu tingkat keyakinan sejauh mana seorang karyawan memihak pada suatu organisasi tertentu yang tujuannya berniat memelihara keanggotaan dalam organisasi itu. Berdasarkan teori keagenan hubungan antara komitmen organisasi pada kinerja manajerial dapat menimbulkan konflik akibat ketidaksamaan kepentingan hubungan antara agen dan prinsipal.

Tinggi rendahnya komitmen organisasi akan sangat menentukan kinerja yang akan dicapai oleh organisasi, komitmen dapat terwujud apabila individu dalam organisasi menjalankan hak dan kewajiban mereka sesuai dengan tugasnya masing-masing dalam organisasi, karena pencapaian tujuan organisasi merupakan hasil kerja semua anggota organisasi yang bersifat kolektif. Komitmen yang tinggi akan membuat individu organisasi berusaha keras mencapai tujuan organisasi guna meningkatan kinerja organisasi. Dalam suatu organisasi kepemimpinan memegang peranan yang sangat penting karena pemimpin yang akan menggerakkan dan mengerahkan organisasi dalam mencapai tujuan dan sekaligus merupakan tugas yang tidak mudah. Bawahan dipengaruhi sedemikian rupa sehingga memberikan pengabdian dan partisipasinya kepada organisasi secara efektif dan efisien. Jadi sukses tidaknya usaha untuk mencapai tujuan organisasi akan ditentukan oleh kualitas pemimpinnya.

Penelitian yang dilakukan oleh Rahmi (2014), Widjaja \& Abdurrahman (2018) yang menyatakan bahwa gaya kepemimpinan transformasional 
berpengaruh positif dan signifikan terhadap komitmen organisasi. Tetapi penelitian ini tidak sejalan dengan penelitian yang telah dilakukan oleh Nugroho (2011) menyatakan bahwa gaya kepemimpinan transformasional tidak berpengaruh signifikan terhadap komitmen organisasi. Berdasarkan uraian tersebut, maka hipotesis yang dapat dirumuskan dalam penelitian ini adalah:

$\mathrm{H}_{5}$ : Gaya kepemimpinan transformasional memperkuat pengaruh komitmen organisasi pada kinerja manajerial.

Burn (1978) mengatakan bahwa kepemimpin transformasional merupakan pemimpin yang dapat memotivasi bawahan untuk bekerja demi tercapainya sasaran organisasi dan memuaskan kebutuhan mereka pada tingkat yang lebih tinggi. Ada tiga cara yang dilakukan seorang pemimpin transformasional untuk memotivasi bawahan agar kinerja mereka mereka semakin meningkat, yaitu dengan cara mendorong karyawannya untuk lebih menyadari arti penting dari hasil usaha mereka, mendorong karyawan untuk mendahulukan kepentingan kelompok dan yang terakhir meningkatkan kebutuhan karyawan yang lebih tinggi seperti harga diri dan aktualitas diri.

Dengan kata lain motivasi merupakan ukuran berapa lama seseorang dapat menjaga usaha mereka. Individu yang termotivasi akan menjalankan tugas dengan cepat untuk mencapai tujuan mereka. Penelitian yang dilakukan oleh Italiani (2013) menyatakan bahwa gaya kepemimpinan transformasional berpengaruh signifikan terhadap kinerja karyawan, Handoyo (2015) menyatakan bahwa terdapat hubungan positif motivasi kerja dengan kinerja karyawan. Tetapi penelitian ini tidak sejalan dengan penelitian yang dilakukan oleh Amalia (2016) yang menyatakan bahwa gaya kepemimpinan transformasional tidak berdampak 
nyata terhadap motivasi kerja. Berdasarkan uraian tersebut, maka hipotesis yang dapat dirumuskan dalam penelitian ini adalah:

$\mathrm{H}_{6}$ : Gaya Kepemimpinan transformasional memperkuat pengaruh motivasi pada kinerja manajerial.

\section{METODE PENELITIAN}

Penelitian ini menggunakan pendekatan kuantitatif yang berbentuk kausalitas.Desain penelitian ini bisa dilihat pada Gambar 1.

\section{Variabel Independen}

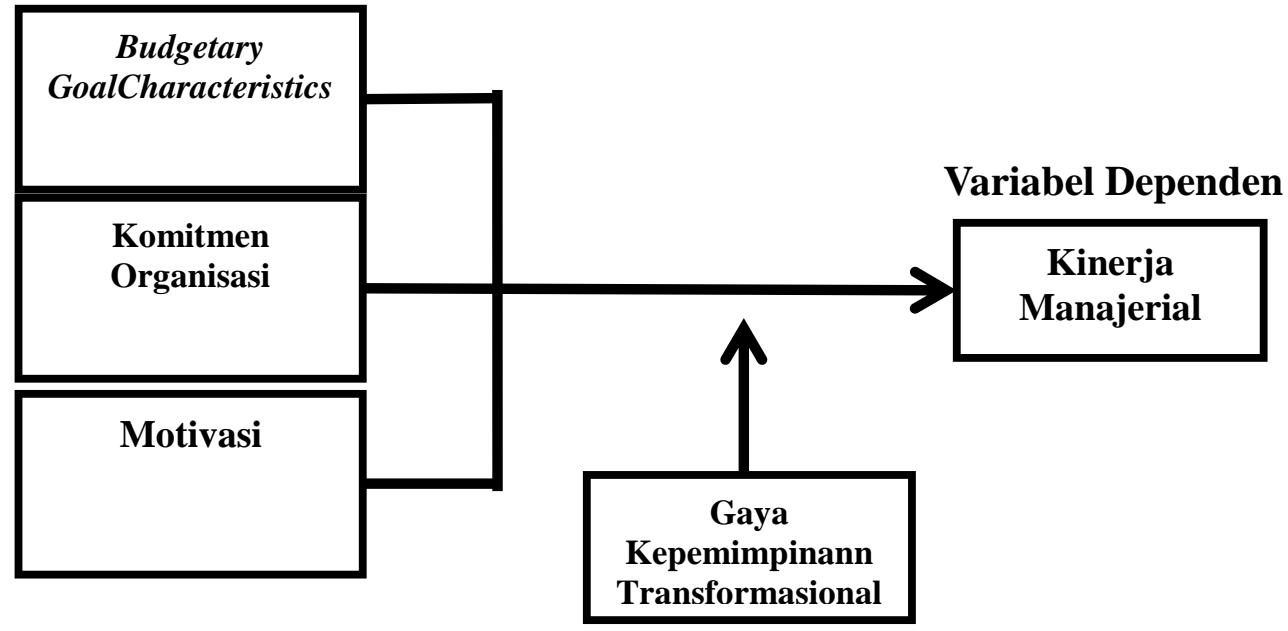

Variabel Moderasi

\section{Gambar 1. Desain Penelitian}

Sumber: Data Diolah, 2017

Lokasi penelitian ini dilakukan pada Pemerintah Kota Denpasar. Alasan pemilihan lokasi penelitian ini karena Pemerintah Kota Denpasar berada pada peringkat kedua dengan pendapatan terbesar di Bali. Sedangkan obyek dalam penelitian ini adalah kinerja manajerial yang dipengaruhi oleh budgetary goal characteristics, komitmen organisasi, dan motivasi dengan gaya kepemimpinan transformasional sebagai variabel moderasi. 
Variabel terikat dalam penelitian ini adalah Kinerja manajerial. Variabel moderasi dalam penelitian ini adalah gaya kepemimpinan transformasional. Sedangkan variabel bebas dalam penelitian ini adalah budgetary goal characteristics $\left(\mathrm{X}_{1}\right)$, komitmen organisasi $\left(\mathrm{X}_{2}\right)$ dan motivasi $\left(\mathrm{X}_{3}\right)$. Seluruh variabel diukur menggunakan skala Likert modifikasi empat poin, yaitu 1 = sangat tidak setuju, 2 = tidak setuju, 3 = setuju, 4 = sangat setuju. Alasannya karena dengan pertimbangan untuk memperoleh pandangan responden secara lebih jelas mengenai pertanyaan-pertanyaan yang disajikan dalam kuisioner.

Jenis data yang digunakan dalam penelitian ini adalah data kuantitatif berupa skor dari jawaban kuisioner yang diajukan kepada responden. Data kualitatif dalam penelitian ini berupa daftar nama-namaorganisasi pada Pemerintah Kota Denpasar. Sedangkan sumber data yang digunakan dalam penelitian ini adalah data primer yang secara langsung diperoleh peneliti melalui sumbernya. Data sekunder yang digunakan dalam penelitian ini berupa jawaban responden terhadap item-item pertanyaan yang telah diberikan oleh peneliti.

Populasi dalam penelitian ini berjumlah 2.487 orang. Sedangkan sampel dalam penelitian ini berjumlah 93 orang. Pengambilan sampel dilakukan dengan teknik purposive sampling. Kriteria sampel yang akan digunakan dalam penelitian ini yaitu Kepala Dinas, Kepala Sub Bagian Umum dan Perencanaan, serta Kepala Sub Bagian Keuangan pada SKPD di Pemerintah Kota Denpasar. Pejabat yang sudah bekerja lebih dari 1 tahun, di asumsikan pejabat yang bekerja lebih dari satu tahun dianggap ikut serta dalam proses penyusunan dan pelaksanaan anggaran 
baik secara sktuktural dan fungsional. Metode pengumpulan data yang digunakan dalam penelitian ini adalah metode angket atau kuisioner.

Teknik analisis data yang digunakan dalam penelitian ini adalah teknik Moderated Regression Analysis (MRA). Sebelum melakukan pengujian, terdapat beberapa asumsi yang harus dipenuhi agar data yang akan dimasukkan dalam model telah memenuhi ketentuan dan syarat dalam regresi. Uji asumsi klasik dalam penelitian ini mencakup uji normalitas, multikolinearitas, dan heteroskedastisitas. Model regresidapat di rumuskan sebagai berikut :

$\mathrm{Y}=\alpha+\beta_{1} \cdot \mathrm{X}_{1}+\beta_{2} \cdot \mathrm{X}_{2}+\beta_{3} \cdot \mathrm{X}_{3}+\beta_{4} \cdot \mathrm{Z}_{4}+\beta_{5}\left(\mathrm{X}_{1} \mathrm{Z}_{4}\right)+\beta_{6}\left(\mathrm{X}_{2} \mathrm{Z}_{4}\right)+\beta_{7}\left(\mathrm{X}_{3} \mathrm{Z}_{4}\right)+$

Keterangan:

$\mathrm{Y}=$ Kinerja Manajerial

$\alpha \quad=$ Konstanta

$\mathrm{X}_{1} \quad=$ Budgetary Goal Characteristics

$\mathrm{X}_{2} \quad=$ Komitmen Organisasi

$\mathrm{X}_{3} \quad=$ Motivasi

$\mathrm{Z} \quad$ = Gaya Kepemimpinan Transformasional

$\beta_{1}-\beta_{4} \quad=$ Koefisien

$\mathrm{e} \quad=$ error

Berdasarkan hasil analisis yang dilakukan dapat diamati mengenai koefisien determinasi ( $\mathrm{R}^{2}$ ), uji kelayakan model (uji F), dan uji hipotesis (uji t).

\section{HASIL DAN PEMBAHASAN}

Karakteristik demografi dalam penelitian ini meliputi jenis kelamin, umur, jabatan, pendidikan terakhir, dan lama menduduki jabatan dapat dilihat pada Tabel 2. Berdasarkan Tabel 2 dapat di ketahui bahwa responden yang berjenis kelamin pria berjumlah 41 orang atau sebesar 44,1 persen dan berjenis kelamin wanita berjumlah 52 orang atau sebesar 55,9 persen. Responden pada penelitian ini rata-rata berusia 41-50 tahun dengan jumlah 31 orang atau sebesar 48,4 persen. 
Tabel 2.

Demografi Responden

\begin{tabular}{clcc}
\hline No & \multicolumn{1}{c}{ Kriteria } & Jumlah & Persentase \\
\hline 1 & Jenis Kelamin & & \\
& Pria & 41 & 44,1 \\
& Wanita & 52 & 55,9 \\
2 & & \\
& Umur & 3 & 8,6 \\
& 20-30 Tahun & 3 & 14 \\
& 31-40 Tahun & 31 & 48,4 \\
& 41-50 Tahun & 23 & 29 \\
> 50 Tahun & & \\
Pendidikan Terakhir & 5 & 5,4 \\
& Sma / Smk & 5 & 5,4 \\
& Diploma & 53 & 57 \\
& S1 & 30 & 32,3 \\
& S2 & 0 & 0 \\
& S3 & & \\
Lama Menduduki Jabatan/ Bagian Tertentu & 40 & 43 \\
& 1-5 Tahun & 25 & 26,9 \\
& 6-10 Tahun & 28 & 30,1 \\
\hline 10 Tahun & & \\
\hline Sumber: Data diolah, 2018 & &
\end{tabular}

Sumber: Data diolah, 2018

Pada tabel pendidikan terakhir diketahui bahwa jumlah responden dengan tingkat penidikan SMA/SMK sebanyak 5 orang $(5,4$ persen), tingkat pendidikan Diploma sebanyak 5 orang (5,4 persen), tingkat pendidikan S1 sebanyak 53 orang (57,0 persen), tingkat pendidikan S2 sebanyak 30 orang (32,3 persen), untuk tingkat pendidikan S3 tidak ada. Responden dengan kriteria lama menduduki jabatan selama 1-5 tahun sebanyak 40 orang atau sebesar 43,0 persen, selama 6-10 tahun sebanyak 25 orang atau sebesar 26,9 persen dan sisanya sebanyak 28 orang atau sebesar 30,1 persen lama menduduki jabatan selama lebih dari 10 tahun.

Uji validitas dilakukan untuk mengukur sejauh mana variabel yang digunakan benar-benar mengukur apa yang seharusnya diukur. Instrumen di katakan valid apabila nilai person corelation terhadap total skor $>0,3$. Berdasarkan Tabel 3 dapat dilihat seluruh indikator pertanyaan lebih besar dari 0,30 sehingga keseluruhan indikator yang digunakan dinyatakan valid. 
Tabel 3.

Hasil Uji Validitas

\begin{tabular}{|c|c|c|c|c|}
\hline No & Variabel & $\begin{array}{c}\text { Kode } \\
\text { Instrumen }\end{array}$ & $\begin{array}{l}\text { Nilai Pearson } \\
\text { Correlation }\end{array}$ & Keterangan \\
\hline \multirow{29}{*}{1} & \multirow{28}{*}{ Budgetary Goal Characteristics } & $\mathrm{X} 1.1 .1$ & 0,746 & Valid \\
\hline & & $\mathrm{X} 1.1 .2$ & 0,927 & Valid \\
\hline & & $\mathrm{X} 1.1 .3$ & 0,833 & Valid \\
\hline & & $\mathrm{X} 1.1 .4$ & 0,84 & Valid \\
\hline & & $\mathrm{X} 1.1 .5$ & 0,539 & Valid \\
\hline & & $\mathrm{X} 1.2 .1$ & 0,903 & Valid \\
\hline & & $\mathrm{X} 1.2 .2$ & 0,542 & Valid \\
\hline & & $\mathrm{X} 1.2 .3$ & 0,828 & Valid \\
\hline & & $\mathrm{X} 1.3 .1$ & 0,844 & Valid \\
\hline & & $\mathrm{X} 1.3 .2$ & 0,666 & Valid \\
\hline & & $\mathrm{X} 1.3 .3$ & 0,868 & Valid \\
\hline & & $\mathrm{X} 1.3 .4$ & 0,885 & Valid \\
\hline & & $\mathrm{X} 1.3 .5$ & 0,871 & Valid \\
\hline & & $\mathrm{X} 1.4 .1$ & 0,84 & Valid \\
\hline & & $\mathrm{X} 1.4 .2$ & 0,813 & Valid \\
\hline & & $\mathrm{X} 1.4 .3$ & 0,9 & Valid \\
\hline & & $\mathrm{X} 1.5 .1$ & 0,89 & Valid \\
\hline & & $\mathrm{X} 1.5 .2$ & 0,79 & Valid \\
\hline & & $\mathrm{X} 1.5 .3$ & 0,583 & Valid \\
\hline & & $X 1.5 .4$ & 0,473 & Valid \\
\hline & & $X 1.5 .5$ & 0,505 & Valid \\
\hline & & $\mathrm{X} 1.5 .6$ & 0,873 & Valid \\
\hline & & $X 1.5 .7$ & 0,828 & Valid \\
\hline & & $\mathrm{X} 1.5 .8$ & 0,651 & Valid \\
\hline & & X1.5.9 & 0,704 & Valid \\
\hline & & $\mathrm{X} 1.5 .10$ & 0,79 & Valid \\
\hline & & $\mathrm{X} 2.1$ & 0,906 & Valid \\
\hline & & $\mathrm{X} 2.2$ & 0,947 & Valid \\
\hline & \multirow{5}{*}{ Komitmen Organisasi } & $\mathrm{X} 2.3$ & 0,832 & Valid \\
\hline \multirow{4}{*}{2} & & X2.4 & 0,909 & Valid \\
\hline & & $\mathrm{X} 2.5$ & 0,881 & Valid \\
\hline & & $\mathrm{X} 2.6$ & 0,939 & Valid \\
\hline & & $X 2.7$ & 0,853 & Valid \\
\hline \multirow[t]{11}{*}{2} & \multirow[t]{6}{*}{ Komitmen Organisasi } & X2.8 & 0,895 & Valid \\
\hline & & $\mathrm{X} 2.9$ & 0,913 & Valid \\
\hline & & X 3.1 & 0,893 & Valid \\
\hline & & $\mathrm{X} 3.2$ & 0,883 & Valid \\
\hline & & X3.3 & 0,924 & Valid \\
\hline & & X3.4 & 0,908 & Valid \\
\hline & \multirow{5}{*}{ Motivasi } & $\mathrm{X} 3.5$ & 0,89 & Valid \\
\hline & & X3.6 & 0,905 & Valid \\
\hline & & X3.7 & 0,905 & Valid \\
\hline & & X3.8 & 0,843 & Valid \\
\hline & & X3.9 & 0,914 & Valid \\
\hline 3 & & $\mathrm{X} 3.10$ & 0,935 & Valid \\
\hline 4 & Kinerja Manajerial & Y1 & 0,769 & Valid \\
\hline
\end{tabular}




$\begin{array}{cccc} & \text { Y2 } & 0,921 & \text { Valid } \\ & \text { Y3 } & 0,968 & \text { Valid } \\ & \text { Y4 } & 0,816 & \text { Valid } \\ & \text { Y5 } & 0,924 & \text { Valid } \\ & \text { Y6 } & 0,849 & \text { Valid } \\ & \text { Y7 } & 0,907 & \text { Valid } \\ & \text { Y8 } & 0,953 & \text { Valid } \\ & \text { Y9 } & 0,872 & \text { Valid } \\ \text { Gaya Kepemimpinan } & \text { Z1 } & 0,954 & \text { Valid } \\ \text { Trabsformasional } & \mathrm{Z} 2 & 0,954 & \text { Valid } \\ & \mathrm{Z} 3 & 0,964 & \text { Valid } \\ & \mathrm{Z} 4 & 0,936 & \text { Valid } \\ & \mathrm{Z} 5 & 0,931 & \text { Valid }\end{array}$

Sumber: Data Diolah, 2018

Pengujian reliabilitas menunjukkan sejauh mana suatu instrumen yang digunakan beberapa kali untuk mengukur suatu obyek yang sama, akan memberikan hasil data yang sama. Hasil uji reliabilitas akan menghasilkan Crombach's Alpha. Jika nilai dari Crombach's Alpha di atas 0,60 maka data dikatakan reliabel. Hasil uji reliabilitas dapat dilihat pada Tabel 4. Berdasarkan Tabel 4 dapat dilihat bahwa seluruh variable memiliki nilai koefisien Crombach's Alpha di atas 0,60 sehingga terbukti reliabel.

Tabel 4.

Hasil Uji Reliabilitas

\begin{tabular}{clcc}
\hline No & \multicolumn{1}{c}{ Variabel } & Cronbach's Alpha & Keterangan \\
\hline 1 & Budgetary Goal Characteristics (X1) & 0,974 & Reliabel \\
2 & Komitmen Organisasi (X2) & 0,970 & Reliabel \\
3 & Motivasi (X3) & 0,974 & Reliabel \\
4 & Kinerja Manajerial (Y) & 0,967 & Reliabel \\
5 & Gaya Kepemimpinan Transformasional (Z) & 0,972 & Reliabel \\
\hline
\end{tabular}
Sumber: Data Diolah, 2018

Uji normalitas menggunakan uji Kolmogorov-Smirnov, dengan uji ini dapat diketahui data yang digunakan berdistribusi normal atau tidak. Apabila Sign $\mathrm{t}$ hitung $>0.05$, maka data tersebut berdistribusi normal dan begitu juga sebaliknya (Santoso, 2001). Berdasarkan Tabel 5 menunjukkan bahwa koefisien Asymp.Sig 
(2-tailed) sebesar 0.200 lebih besar dari 0,05. Hal ini berarti data dalam penelitian ini berdistribusi normal.

Tabel 5.

Hasil Uji Normalitas

\begin{tabular}{llr}
\hline & & Unstandardized Residual \\
\hline $\mathrm{N}$ & & 93 \\
Normal Parameters $^{\mathrm{a}, \mathrm{b}}$ & Mean &, 0000000 \\
& Std. Deviation & 4,40580970 \\
Most Extreme Differences & Absolute &, 078 \\
& Positive &, 078 \\
& Negative &,- 045 \\
Test Statistic & &, 078 \\
Asymp. Sig. (2-tailed) & &, $200^{\mathrm{c}, \mathrm{d}}$ \\
\hline Sumber: Data Diolah, 2018 & &
\end{tabular}

Uji Heterokedastisitas dilakukan untuk menguji apakah dalam model regresi terjadi ketidaksamaan varian dari residu satu pengamatan ke pengamatan lain. Apabila model suatu regresi mengandung gejala heterokedastisitas, maka hasil yang diberikan akan menyimpang. Untuk mengetahui apakah sebuah regresi memiliki indikasi heterokedastisitas, maka masalah tersebut bisa dideteksi dengan menggunakan uji Glejser Test. Jika probabilitas signifikansinya di atas 0,05 maka dapat dikatakan bahwa pada model regresi tidak mengandung masalah heterokedastisitas . Hasil uji heterokedastisitas dapat dilihat pada Tabel 6.

Berdasarkan hasil tersebut dapat dilihat bahwa nilai signifikan masingmasing variabel diatas $\alpha=0,05$. Jadi dapat disimpulkan bahwa model regresi dalam penelitian ini bebas dari gejala heteroskedastisitas. 
Tabel 6.

Hasil Uji Heteroskedastisitas

\begin{tabular}{llll}
\hline Model & Variabel & T & Sig. \\
\hline & X1 & 0,543 & 0,588 \\
& Z & 0,130 & 0,897 \\
& X1_Z & $-0,337$ & 0,737 \\
Regresi I & X2 & 0,610 & 0,543 \\
& Z & 0,130 & 0,897 \\
& X2_Z & $-0,553$ & 0,581 \\
& X3 & $-0,851$ & 0,397 \\
& Z & 0,130 & 0,897 \\
& X3_Z & 1,471 & 0,145 \\
\hline
\end{tabular}

Sumber: Data diolah, 2018

Uji multikolinieritas digunakan untuk mengetahui apakah antara variabel bebas terjadi multikolinieritas atau tidak.Uji yang digunakan yaitu dengan melihat nilai VIF (Varian Inflation Factor) dan Tolerance pada proses regresi biasa, jika keduanya mendekati 1 atau besaran VIF kurang dari 10 maka model tidak terkena multikolinieritas. Berdasarkan Tabel 7 dapat disimpulkan bahwa nilai tolerance variabel bebas di atas 0,1 dan nilai VIF di bawah 10 yang berarti bahwa tidak ada multikolinearitas variabel bebas dalam penelitian ini.

Tabel 7. Hasil Uji Multikolinearitas

\begin{tabular}{|c|c|c|c|}
\hline Model & Variabel & Tolerance & VIF \\
\hline \multirow{9}{*}{ Regresi I } & X1 & 0,784 & 1,275 \\
\hline & $\mathrm{Z}$ & 0,527 & 1,897 \\
\hline & X1_Z & 0,422 & 2,371 \\
\hline & $\mathrm{X} 2$ & 0,811 & 1,234 \\
\hline & $\mathrm{Z}$ & 0,527 & 1,897 \\
\hline & X2_Z & 0,630 & 1,589 \\
\hline & X3 & 0,750 & 1,333 \\
\hline & $\mathrm{Z}$ & 0,527 & 1,897 \\
\hline & X3_Z & 0,806 & 1,24 \\
\hline
\end{tabular}

Sumber: Data diolah, 2018

Hasil analisis regresi moderasi dapat dilihat pada Tabel 8 di atas. Berdasarkan Tabel 8 dapat dilihat persamaan sebagai berikut.

$$
\begin{gathered}
\mathrm{Y}=32,792-0,075 \mathrm{X} 1+0,337 \mathrm{X} 2-0,749 \mathrm{X} 3-1,443 \mathrm{Z}+0,014 \mathrm{X} 1 \mathrm{Z}-0,004 \mathrm{X} 2 \mathrm{Z}+ \\
0,041 \mathrm{X} 3 \mathrm{Z}
\end{gathered}
$$


Tabel 8.

Hasil Uji Moderated Regresion Analysis

\begin{tabular}{llccccc}
\hline & \multicolumn{7}{c}{$\begin{array}{c}\text { Unstandardized } \\
\text { Coefficients }\end{array}$} & $\begin{array}{c}\text { Standardized } \\
\text { Coefficients }\end{array}$ & & \\
Model & B & Std. Error & Beta & T & Sig. \\
\hline 1 & (Constant) & 32,729 & 10,770 & & 3,039 &, 003 \\
& X1 &,- 075 &, 085 &,- 170 &,- 891 &, 375 \\
X2 &, 337 &, 191 &, 343 & 1,765 &, 081 \\
X3 &,- 749 &, 194 &,- 860 & $-3,864$ &, 000 \\
Z & $-1,443$ &, 750 &,- 824 & $-1,924$ &, 058 \\
X1_Z &, 014 &, 006 &, 910 & 2,152 &, 034 \\
X2_Z &,- 004 &, 012 &,- 093 &,- 295 &, 769 \\
& X3_Z &, 041 &, 013 &, 537 & 3,015 &, 003 \\
Adjusted R Square &, 640 & & & & \\
F & 24,366 & & & & \\
Sig. & $.000^{\mathrm{a}}$ & & & & &
\end{tabular}

Sumber: Data diolah, 2018

Jika nilai konstanta $(\alpha)$ sebesar 32,792 memiliki arti apabila budgetary goal characteristics (X1), komitmen organisasi (X2), motivasi (X3), gaya kepemimpinan transformasional (Z) sama dengan nol, maka nilai kinerja manajerial (Y) sebesar 32,729 satuan.

Berdasarkan Tabel 8 bahwa nilai adjusted Rsquare $\left(\mathrm{R}^{2}\right)$ sebesar 0,640 atau 64,0\%. Hal ini berarti bahwa budgetary goal characteristics, komitmen organisasi, motivasi, gaya kepemimpinan transformasional dan interaksi antara budgetary goal characteristics, komitmen organisasi, motivasi dengan gaya kepemimpinan transformasional mempegaruhi kinerja manajerial sebesar 64,0 dan sisanya sebesar 36,0\% di pengaruhi oleh variabel lain di luar penelitian.

Berdasarkan Tabel 8 dapat dilihat bahwa nilai $\mathrm{F}$ sebesar 24,366 dengan signifikan sebesar 0,000 yang berarti bahwa nilai signifikan lebih kecil 0,05 hal ini berarti bahwa budgetary goal characteristics, komitmen organisasi, motivasi, gaya kepemimpinan transformasional, interaksi antara budgetary goal characteristics, komitmen organisasi, motivasi dengan gaya kepemimpinan 
transformasional secara bersama-sama berpengaruh pada kinerja manajerial, pada tingkat signifikansi 5 persen dan menunjukkan bahwa model regresi berganda layak digunakan sebagai alat analisis.

Berdasarkan data yang disajikan pada Tabel 8 diketahui bahwa interaksi antara variabel budgetary goal characteristics dengan kinerja manajerial memiliki tingkat signifikan sebesar 0,375 lebih besar dari alpha 0,05 . Hal ini berarti bahwa $\mathrm{H}_{0}$ diterima dan $\mathrm{H}_{1}$ ditolak, yang artinya bahwa hipotesis 1 yang menyatakan bahwa budgetary goal characteristics berpengaruh positif pada kinerja manajerial ditolak $\left(\mathrm{H}_{1}\right.$ ditolak).

Hal ini dikarenakan bawahan tidak memiliki pengaruh yang besar dalam menentukan sasaran dari anggaran yang mereka susun. Bawahan juga kurang memahami mengenai sasaran yang di prioritaskan pada anggaran, serta banyaknya kesulitan yang dihadapi dalam mencapai sasaran anggaran. Sehingga menyebabkan kinerja bawahan terlihat tidak meningkat.

Hasil penelitian ini didukung oleh penelitian yang dilakukan oleh Ratnawati, (2014) dan Murthi \& Sujana (2008) yang menyatakan bahwa budgetary goal characteristics tidak berpengaruh terhadap kinerja manajerial, Rassuli (2012) menyatakan bahwa partisipasi anggaran, kejelasan sasaran anggaran, kesulitan sasaran anggaran dan evaluasi anggaran tidak berpengaruh terhadap kinerja organisasi.

Berdasarkan data yang disajikan pada Tabel 8 diketahui bahwa interaksi antara variabel komitmen organisasi dengan kinerja manajerial memiliki tingkat 
signifikan sebesar 0,081 lebih kecil dari alpha 0,05. Hal ini berarti komitmen organisasi berpengaruh positif pada kinerja manajerial diterima $\left(\mathrm{H}_{2}\right.$ diterima $)$.

Hal ini dikarenakan adanya kontrak yang mengikat bawahan untuk melakukan komitmen terhadap organisasi. Sehingga bawahan kan menaruh kepentingan organisasi diatas kepentingan pribadi mereka. Dengan bawahan memiliki komitmen yang tinggi terhadap organisasi maka bawahan akan lebih termotivasi untuk meningkatkan kinerja mereka demi mencapai tujuan organisasi.

Penelitian ini didukung oleh penelitian yang telah dilakukan oleh Ikramuddin (2009), Juita (2013) menyatakan bahwa komitmen organisasi berpengaruh signifikan positif terhadap kinerja manajerial, Putri (2010) menyatakan bahwa komitmen organisasional berpengaruh terhadap kinerja manajerial.

Berdasarkan data yang disajikan pada Tabel 8 diketahui bahwa interaksi antara variabel motivasi dengan kinerja manajerial memiliki tingkat signifikan sebesar 0,000 lebih kecil dari alpha 0,05. Hal ini berarti bahwa motivasi berpengaruh positif pada kinerja manajerial diterima $\left(\mathrm{H}_{3}\right.$ diterima $)$.

Hal ini dikarenakan dengan adanya kontrak yang mengikat bawahan, mereka akan lebih termotivasi untuk meningkatkan kinerja mereka. Bawahan juga akan lebih terdorong untuk mencapai tujuan organisasi. Dengan termotivasinya bawahan kinerja mereka akan jauh lebih meningkat.

Penelitian ini di dukung oleh penelitian yang telah dilakukan oleh Caroline (2013) yang menyatakan bahwa motivasi berpengaruh positif dan signifikan 
terhadap kinerja manajerial, Handoyo (2015) menyatakan bahwa terdapat hubungan positif motivasi kerja dengan kinerja karyawan.

Berdasarkan data yang disajikan pada Tabel 8 diketahui bahwa hasil dari pengujian hipotesis menunjukkan bahwa interaksi antara variabel budgetary goal characteristics dengan gaya kepemimpinan transformasional memiliki tingkat signifikan sebesar 0,034 lebih kecil dari alpha 0,05. Hal ini berarti gaya kepemimpinan transformasional memoderasi pengaruh budgetary goal characteristics pada kinerja manajerial diterima ( $\mathrm{H}_{4}$ diterima).

Hal ini dikarenakan seorang pemimpin yang menganut gaya kepemimpinan transformasional akan membuat bawahannya merasa lebih dihargai dengan di berikan kesempatan untuk ikut berpartisipasi, ide-ide maupun pendapat yang mereka kemukakan akan diterima oleh atasan sehingga akan mempengaruhi kinerja mereka. Dengan banyaknya partisipasi bawahan yang di terima oleh atasan, sasaran anggaran akan menjadi jelas dan mudah dicapai oleh bawahan. Bawahan akan merasakan evaluasi dan umpan balik dari pencapaian anggaran yang telah mereka lakukan.

Hasil penelitian ini didukung dengan penelitian yang dilakukan oleh Syafrizal \& Aknawal (2011) karakteristik tujuan anggaran berpengaruh positif terhadap kinerja manajerial, Arifin (2012) menyatakan bahwa partisipasi anggaran berpengaruh secara signifikan terhadap kinerja aparat, Apsari (2013) menyatakan bahwa budgetary goal characteristics memiliki pengaruh positif dan signifikan terhadap kinerja manajerial. 
Berdasarkan data yang disajikan pada Tabel 8 diketahui bahwa hasil dari pengujian hipotesis menunjukkan bahwa interaksi antara variabel komitmen organisasi dengan gaya kepemimpinan transformasional memiliki tingkat signifikan sebesar 0,769 lebih besar dari alpha 0,05. Hal ini berarti gaya kepemimpinan transformasional memoderasi pengaruh komitmen organisasi pada kinerja manajerial ditolak $\left(\mathrm{H}_{5}\right.$ ditolak).

Hal ini membuktikan bahwa gaya kepemimpinan transformasional tidak dapat mempengaruhi komitmen organsasi bawahan. Ini dikarenakan para karyawan pada SKPD Pemerintah Kota Denpasar sudah memiliki ikatan dinas sebagai Pegawai Negeri Sipil (PNS) jadi bawahan pasti akan berkomitmen organisasi yang tinggi kepada organisasi. Atasan dengan gaya kepemimpinan transformasional tidak akan mempengaruhi komitmen organisasi walaupu intensitas penerapan gaya kepemimpinan transformasional tinggi bawahan akan tetap berkomitmen terhadap organisasi tersebut.

Hasil ini didukung oleh penelitian yang dilakukan oleh Nugroho (2011) menyatakan bahwa gaya kepemimpinan transformasional tidak berpengaruh signifikan terhadap komitmen organisasi.

Berdasarkan data yang disajikan pada Tabel 8 diketahui bahwa hasil pengujian hipotesis menunjukkan bahwa interaksi antara variabel motivasi dengan gaya kepemimpinan transformasional memiliki tingkat signifikan sebesar 0,003 lebih kecil dari 0,05 . Hal ini berarti gaya kepemimpinan transformasional memoderasi pengaruh motivasi pada kinerja manajerial diterima $\left(\mathrm{H}_{6}\right.$ diterima $)$. 
Hal ini dikarenakan dengan atasan yang memiliki gaya kepemimpinan transformasional bawahan akan terdorong untuk lebih menyadari pentingnya hasil dari kinerja mereka, bawahan akan lebih terdorong untuk mendahulukan kepentingan organisasi dibandingkan dengan kepentingan mereka sendiri, dan bawahan akan merasa memiliki aktualitas diri yang tinggi sehingga kinerja dari bawahan akan lebih meningkat.

Hasil penelitian ini didukung dengan penelitian yang dilakukan oleh Goeyanto (2012), Handoyo (2015) yang menyatakan bahwa terdapat hubungan positif motivasi kerja dengan kinerja karyawan, Khoirusmandi (2011) menyatakan bahwa kepemimpinan trasnformasional berpengaruh secara positif signifikan terhadap kinerja pegawai.

\section{SIMPULAN}

Berdasarkan pembahasan hasil penelitian di atas, dapat disimpulkan bahwa Budgetary goal characteristics berpengaruh negatif pada kinerja manajerial. Komitmen organisasi dan motivasi berpengaruh positif pada kinerja manajerial. Gaya kepemimpinan transformasional memperkuat pengaruh budgetary goal characteristics pada kinerja manajerial. Gaya kepemimpinan transformasional memperlemah pengaruh komitmen organisasi pada kinerja manajerial. Gaya kepemimpinan transformasional memperkuat pengaruh motivasi pada kinerja manajerial. Sedangkan saran yang dapat diberikan yaitupejabat atau pemimpin agar lebih meningkatkan gaya kepemimpinan transformasional sehingga bawahan akan lebih meningkatkan komitmen mereka terhadap organisasi walaupun 
bawahan sudah terikat dengan organisasi. Selain itu manajer harus lebih menghargai ide-ide yang telah disampaikan oleh bawahan dan atasan memberitahukan hasil kinerja bawahan sehingga bawahan yang mengetahui hasil kinerjanya akan lebih termotivasi lagi untuk meningkatkan kinerja mereka.

\section{REFERENSI}

Apsari, N. M. S. (2013). Pengaruh Budgetary Goal Characteristics Terhadap Kinerja Manajerial dengan Komitmen Organisasi Sebagai Variabel Moderating Pada Rumah Sakit Pemerintah di Kota Denpasar. Skripsi Fakultas Ekonomi Universitas Udayana.

Arifin, S. (2012). Partisipasi Penyusunan Anggaran Terhadap Kinerja Aparat Pemerintah Daerah: Komitmen Organisasi, Budaya Organisasi, dan Gaya Kepemimpinan Sebagai Variabel Moderasi. Skripsi Fakultas Ekonomika Dan Bisnis Universitas Diponogoro.

Burn, J. M. (1978). Leadership. New York: Harper \& Row.

Brownell, P. and McInnes, M. (1986). Budgetary Participation, Motivation, and Managerial Performance. The Accounting Review, 61(4), 87-600.

Caroline, S. A. (2013). Pengaruh Partisipasi Anggaran, Motivasi dan Evaluasi Terhadap Kinerja Manajerial (Studi Empiris Pada Pemerintah Kabupaten Situbondo). Skripsi Fakultas Ekonomi Universitas Jember.

Cavazotte, F., Moreno, V., Hickman, M. (2012). Effects of Leader Intelligence, Personalityand Emotional Inteligence On Transformasional Leadership an Managerial Performance. The Leadership Quartely, 23(3), 443-445.

Chipunza, C., Michael, O., and Tendai, M. (2011). Leadership Style, Employee Motivation and Commitment: Empiricial Evidence from A Consolidated Retail Bank Operating in A Depressed Economy. African Journal of Bussiness Management, 5(20), 8337-8346.

Dewi, I. C. dan Nuri, H. (2010). Analisis Dampak Kepemimpinan Transaksional dan Transformasional terhadap Pembelajaran Organisasi pada PT. Bangunan Satya Wacana Surabaya. Jurnal Manajemen Teori dan Terapan, $3(3), 1-15$.

Eisenhardt, K. (1989). Agency theory: An assessment and review. Academy of Management Review, 14, 57-74. 
Eker, M. (2007). The Impact Of Budget Participation on Managerial Performance Via Organizational Commitment: A Study on The Top 500 Firms In Turkey. Ankara Universitesi SBF Dergisi, 64-4.

Goeyanto, F. (2012). Analisis Pengaruh Kepemimpinan Transaksional, Motivasi, dan Komitmen Organisasional Terhadap Kepuasan Kerja Dalam Meningkatkan Kinerja Karyawan. Jurnal Universitas Katolik Widya Mandala Surabaya, 1(6).

Govindarajan, V. (1986). Impact of Participation in the Budgetary Process on Managerial Attitudes and Performance: Universalistic and Contingency Perspective. Decision Sciences, 496-516.

Handoko, T. H. (1996). Manajemen. Yogyakarta: BPFE.

Handoyo, L. N. (2015). The Influence of Leadership Styles on Employee's Performance Through Work Motivation (An Organizational Study at Four Hotels in Malang). Jurnal Administrasi Bisnis (JAB), 22(1).

Hapsari, A. R. (2010). Pengaruh Partisipasi Penyusunan Anggaran terhadap Kinerja manajerial dengan Komitmen Organisasi dan Locus Of Control sebagai Variabel Moderating. Skripsi Fakultas Ekonomi Universitas Diponegoro.

Ikramuddin. (2009). Pengaruh Partisipasi Anggaran, Kepemimpinan dan Komitmen Organisasi terhadap Kinerja Manajerial pada SKPD Kota Lhokseumawe. Jurnal Akuntansi Universitas Malikussaleh Lhokseumawe.

Italiani, F. A. (2013). Pengaruh Gaya Kepemimpinan Transformasional dan Transaksional Terhadap Kinerja Pegawai Departemen SDM PT. Semen Gresik (PERSERO) Tbk. Jurnal Bisnis Dan Manajemen Fakultas Ekonomi UNESA, 6(1), 11-18.

Juita, S. D. (2013). Pengaruh Kualitas Sumber Daya Manusia, Komitmen Organisasi dan Komunikasi Organisasi terhadap Kinerja Satuan Kerja Perangkat Daerah (SKPD) (Studi Empiris pada SKPD Pemerintah Kota Padang). Skripsi Fakultas Ekonomi Universitas Negeri Padang.

Kenis, I. (1979). Effects of Budgetary Goal Characteristics on Managerial Attitudes and Performance. The Accounting Review, 54(4), 707-721.

Khoirusmandi, A. S. (2011). Analisis Pengaruh Kepemimpinan Transformasional Terhadap Kinerja Pegawai dengan Budaya Organisasi Sebagai Variabel Intervening. Skripsi Fakultas Ekonomi Universitas Diponegoro. 
Mahoney, T. A., Jerdee, T. H., \& Carroll, S. J. (1965). The Job(s) of Management. Industrial Relations: A Journal of Economy and Society, 4(2), 97-110.

Mardiasmo. (2009). Akuntansi Sektor Publik. Yogyakarta: Andi.

Maiga, A. S. and Jacobs, F. A. (2008). The Moderating Effect Manager's Ethical Judgment On The Relationship Between Budget Participation and Budget Slack. Advances In Accounting, 23, 113-145.

Murthi, I. A. M. M., \& Sujana, I. K. (2008). Pengaruh Budgetary Goal Characteristics terhadap Kinerja Manajerial pada Rumah Sakit Pemerintah di Kota Denpasar. Jurnal Akuntansi Dan Bisnis, 4(2), 178-188.

Nouri, H. dan Parker, R. J. (1996). The Effect of Organisational Commitment and Relation between Budgetary and Budgetary Slack. Behavior Research in Accounting, 8, 4-89.

Nugraha, G. A., \& Aldila, D. (2018). Pengaruh Struktur dan Kultur Organisasi terhadap Keefektifan Partisipasi Anggaran dalam Peningkatan Kinerja Manajerial: Studi Empiris Pada Lembaga Keuangan Syariah. Jurnal Ilmiah Akuntansi, 16(1), 21-33.

Nugroho, D. A. (2011). Pengaruh Budaya Organisasi Dan Gaya Kepemimpinan Transformasional Terhadap Komitmen Organisasi Dan Kinerja Pegawai. Jurnal Manajemen Bisnis, 1(2).

Putri, N. D. (2010). Pengaruh Komitmen Organisasional dan Peran Manajer Pengelolaan Keuangan Daerah Terhadap Kinerja Manajerial Satuan Kerja Perangkat Daerah (Studi Pada Kabupaten Tegal). Skripsi Fakultas Ekonomi Universitas Diponegoro.

Rahmi, B. M. (2014). Pengaruh Kepemimpinan Transformasional Terhadap Organizational Citizenship Behavior dan Komitmen Organisasional dengan Mediasi Kepuasan Kerja (Studi pada Guru Tetap SMA Negeri di Kabupaten Lombok Timur). Tesis Magister Manajemen Universitas Udayana.

Ratnawati, K. (2014). Pengaruh Budgetary Goal Characteristics pada Kinerja Manajerial dengan Budaya Paternalistik dan Komimen Organisasi sebagai Moderating Variabel pada Perguruan Tinggi Swasta Kopertis Wilayah III. Simposium Nasional Akuntansi VII.

Satriowati, E., Dhiana, P. P., \& Budi, H. L. (2016). Pengaruh Gaya Kepemimpinan Transformasional, Konpesasi dan Komunikasi Terhadap Kinerja Karyawan dengan Kepuasan Kerja Sebagai Variabel Moderasi Pada Laundry Elephant King. Journal Of Management, 2(2), 1-13. 
Syafrizal, S. H., \& Aknawal, C. (2011). Pengaruh Karakteristik Tujuan Anggaran terhadap Kinerja Manajerial dengan Komitmen Organisasi Sebagai Variabel Moderating pada Pemerintah Kota Banda Aceh. Jurnal E-Mabis FE-Unimal, 12(2).

Widjaja, M. Y. A., \& Abdurrahman, M. Y. M. (2018). Pengaruh Budaya Organisasi dan Gaya Kepemimpinan Transformasional-Transaksional terhadap Kinerja Karyawan melalui Komitmen Organisasi dan Kepuasan Kerja pada Yayasan Nurul Hayat. Jurnal Bisnis Dan Manajemen, 11, 77103. 